\title{
57 (1235)
}

The influence of diet on the heat production during mechanical work in the dog.

\section{By GrahaM Lusk.}

\section{[From the Physiological Laboratory of the Cornell University}

Medical College in New York City.]

The following table shows that when a dog runs at the rate of about $2 \frac{1}{2}$ miles an hour the heat production is almost exactly the same whether the dog has had no food or whether 70 grams of glucose have been administered. In the resting dog 70 grams of glucose would have increased the heat production six calories.

Influence of Food and Mechanical Work on the Metabolism of Dog XV, WeIGHING 9.5 KG.

Results are given in hourly periods.

\begin{tabular}{|c|c|c|c|c|c|}
\hline x917. & Calories. & R. Q. & $\begin{array}{c}\text { Work } \\
\text { in } \\
\text { Meters } \\
\text { Trav- } \\
\text { eled. }\end{array}$ & \begin{tabular}{|c} 
Calories \\
Above \\
Basal \\
per \\
1,ooo M. \\
Trav- \\
eled.
\end{tabular} & $\begin{array}{l}\text { Energy } \\
\text { in Kgm. } \\
\text { to Move } \\
\text { I Ko. } \\
\text { 工 M. }\end{array}$ \\
\hline 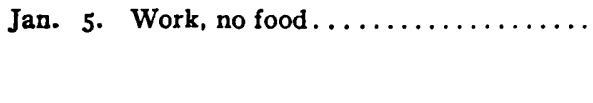 & $\begin{array}{l}6 \mathrm{r} .3 \\
6 \mathrm{r} .0 \\
6 \mathrm{r} . \mathrm{I}\end{array}$ & $\begin{array}{l}0.80 \\
0.77\end{array}$ & $\begin{array}{l}4,140 \\
4,080 \\
4,110\end{array}$ & I0.5 & 0.470 \\
\hline Jan. 6. Work, glucose $70 \mathrm{~g} . \ldots \ldots \ldots \ldots$ & $\begin{array}{l}62.8 \\
62.1 \\
62.5\end{array}$ & $\begin{array}{l}0.96 \\
0.97\end{array}$ & $\begin{array}{l}4,080 \\
4,100\end{array}$ & 10.8 & 0.485 \\
\hline $\begin{array}{r}\text { Jan. 8. Basal } \ldots \ldots \ldots \ldots \ldots \ldots \\
\text { Average. } \ldots \ldots \ldots \ldots\end{array}$ & $\begin{array}{l}19.5 \\
16.4 \\
18.0\end{array}$ & $\begin{array}{l}0.78 \\
0.89 \\
0.84\end{array}$ & & & \\
\hline Work, no food................ & $\begin{array}{l}60.0 \\
67.1 \\
63.5\end{array}$ & $\begin{array}{l}0.94 \\
0.83\end{array}$ & $\begin{array}{l}4,410 \\
4,190 \\
4,300\end{array}$ & 10.6 & 0.475 \\
\hline Jan. 9. Work + glucose $70 \mathrm{~g} .$. & 64.8 & 1.04 & 4,350 & I0.8 & 0.485 \\
\hline Jan. Ir. Work + meat $700 \mathrm{~g} . \ldots \ldots \ldots \ldots$ & $\begin{array}{r}74.0 \\
81.7 \\
\end{array}$ & $\begin{array}{l}0.85 \\
0.81\end{array}$ & $\begin{array}{l}4,190 \\
4,290 \\
\end{array}$ & $\begin{array}{l}13.4 \\
14.4\end{array}$ & \\
\hline Less results after " work, no food " .... & $\begin{array}{l}77.9 \\
63.5\end{array}$ & & 4,240 & & \\
\hline Specific dynamic action of meat..... & 14.4 & $\begin{array}{c}\text { which } \\
\text { bas } \\
\text { incr } \\
\text { hou } \\
\text { the }\end{array}$ & $\begin{array}{l}\text { is } 80 \\
\text { met } \\
\text { ease du } \\
r \text { is } 10 \\
\text { basal } \mathrm{m}\end{array}$ & $\begin{array}{l}\text { er cent. } \\
\text { abolism } \\
\text { lring the } \\
\text { o per } \\
\text { netaboli }\end{array}$ & $\begin{array}{l}\text { of the } \\
\text { The } \\
\text { esecond } \\
\text { cent. of } \\
\text { ism. }\end{array}$ \\
\hline
\end{tabular}


The experiment proves the economical use of carbohydrate during periods of work. On the contrary, when 700 grams of meat were given and the dog was compelled to run, the heat production was increased by that quota which would have been added from the specific dynamic action of the protein metabolized. The latter observation confirms Rubner; the first observation has never been reported. The principles are of importance in the proper arrangement of dietaries for those who execute mechanical labor.

$$
58 \text { (1236) }
$$

\section{The cerebrosides of brain tissue.}

\section{By P. A. Levene and C. J. West.}

\section{[From the Rockefeller Institute for Medical Research, N. Y.]}

Since the work of Thudichum, evidence has existed that there was more than one cerebroside. On the basis of physical properties and analyses, Thudichum distinguished two cerebrosides, phrenosin and kerasin. He had the correct intuition as to the points of difference of the two cerebrosides, and suggested that this difference was in the nature of one component, namely, the fatty acid. As far as he worked, the other components were identical in all cerebrosides. Unfortunately his method of separation was imperfect. Therefore, each fraction contained a large portion of the other. When the fatty acids were obtained, they analyzed approximately for a stearic acid, which Thudichum named neuro stearic acid. Subsequent workers improved the methods of purification particularly that of phrenosin; this permitted the isolation of the fatty acid, cerebronic acid. This acid was identified by Thierfelder as an hydroxy pentacosanic acid, $\mathrm{C}_{25} \mathrm{H}_{50} \mathrm{O}_{3}$. The further work on cerebrosides brought nothing new as regards their structure. The attempt of Thierfelder to classify them on the basis of their sugar contents was futile. Finally, it was possible to isolate from a cerebroside corresponding to Thudichum's kerasin, a fatty acid of different structure from cerebronic acid, namely, lignoceric acid. This acid was isolated nearly simultaneously in three laboratories, but its relation to cerebronic and lignoceric acids was first established in our laboratory, and independently of us by Rosenheim. Since then, it has 